\title{
Haematological Changes in Peripheral Blood of HIV - Infected Persons with Correlation to CD4 Cell Count
}

\author{
MM RAHMAN ${ }^{\mathrm{a}}$, S GITI ${ }^{\mathrm{b}}$, MS ISLAM ${ }^{\mathrm{c}}$, MM RAHMAN ${ }^{\mathrm{d}}$
}

Summary:

Objective: Aims at recognizing the haematological abnormalities in peripheral blood associated with HIV infection and to correlate the haematological abnormalities with CD4 cell count to highlight these manifestations with disease progression.

Methodology: Observational cross sectional study.

Setting: Department of Haematology, Armed Forces Institute of Pathology (AFIP), Dhaka cantonment.

Patients: Two hundred four (204) HIV - infected patients receiving antiretroviral therapy aged from three years to 65 years. There were 132 male and 72 female patients.

Results: Anaemia was found in 103 (50.5\%) cases. Leucopenia and thrombocytopenia were observed in ten (4.9\%) and seven (3.4\%) cases respectively. Lymphopenia

Introduction:

Acquired immunodeficiency syndrome (AIDS) was first recognized in 1981 and human immunodeficiency virus (HIV) was identified in $1983^{1}$. Globally the phenomenon of HIV/AIDS is best viewed as a pandemic affecting nearly all the countries of the world ${ }^{2}$. The first case of HIV/AIDS in Bangladesh was detected in 1989. Since then 1495 cases of HIV/AIDS have been reported (as of December 2008). However, UNAIDS estimates that the number of people living with HIV in the country may be as high as 12000 , which is within

a. Lt Col (Dr) Md. Mizanur Rahman, Classified Specialist in Pathology, Armed Forces Institute Pathology (AFIP), Dhaka Cantonment.

b. Col (Dr) Susane Giti, Classified Specialist in Pathology, AFIP, Dhaka Cantonment.

c. Maj Gen (Dr) Md. Saiful Islam, Commandant and Classified Specialist in Pathology, AFIP, Dhaka Cantonment.

d. Dr. Md. Mostafizur Rahman, Assistant Professor, Department of Statistic, Engineering University School and College, Polasi, Dhaka

Address of correspondence: Lt Col (Dr) Md Mizanur Rahman, Classified Specialist in Pathology (Haematology), AFIP, Dhaka Cantonment, e-mail: mizan142004@yahoo.com Mobile: 01726990942.

Received: 15 May, 2013

Accepted: 10 January, 2014 was found in 12 (5.9\%) cases. In 50 (24.5\%) cases Erythrocyte Sedimentation Rate (ESR) was $>20 \mathrm{~mm}$ at the end of $1^{\text {st }}$ hour. Flow cytometric analysis for CD4 cell count showed $<200$ cells/cmm in 65 (31.8\%) cases, in between 200 cells/cmm and 499 cells/cmm in 117 (57.4\%) cases and $>500$ cells/cmm in 22 (10.8\%) cases.

Conclusion: Haematological abnormalities are common in HIV - infected patients and responsible for significant morbidity and mortality in these patients. These abnormalities are more frequent with disease progression. The present study revealed a significant increase in the number of anaemia, leucopenia, lymphopenia and thrombocytopenia with decreasing CD4 cell count.

Keywords: CD4 cell count, Haematological abnormalities, HIV, Peripheral blood.

(J Banagladesh Coll Phys Surg 2014; 32: 130-136)

the range of the low estimate by UNICEF's State of the World's Children Report 20093.

Peripheral blood changes commonly seen in human immunodeficiency virus - infected individuals and disease associated with HIV may reflect disease elsewhere in the body, may result from treatment for that disease, may reflect an attempt to attack the HIV itself, or may seem to be isolated haematological disorders ${ }^{4}$.

The CD4+ lymphocyte is the primary target of HIV infection and leads to progressive impairment of cellular function, characterized by a gradual decline in peripheral blood CD4+ lymphocyte levels ${ }^{5}$.

This study aims at recognizing the haematological abnormalities associated with HIV infection, to correlate the haematological abnormalities with CD4 cell count and to highlight these manifestations with disease progression.

Materials and Methods:

This observation cross - sectional study was carried out at Armed Forces Institute of Pathology (AFIP) in the department of haematology during a period of eight months from June 2012 to January 2013. A total of 204 HIV - infected patients on antiretroviral therapy (AZT) 
irrespective of age and sex from a Non-government Organization (NGO) were included in this study. All the patients were brought to AFIP by a representative of that NGO for blood sampling. Ethical issues were properly addressed and also cleared by the ethical committee of Directorate General of Medical Services (DGMS) of Bangladesh Armed Forces. About two ml venous blood in EDTA bottle was taken for complete haemogram and CD4 cell count. Complete haemogram was performed by automated haematology analyzer Sysmex XT 1800i. Before running the specimen, the analyzer was calibrated by low, normal and high control supplied by the manufacturer. Erythrocyte Sedimentation Rate (ESR) was done by Westergren method. CD4 lymphocyte count was done by Partec Flow Cytometer (cyFlow), an automated multicolour system that performs both analysis and sorting using dual lasers $488 \mathrm{~nm}$ air cooled argon-ion blue and 532 $\mathrm{nm}$ green diode solid state laser. Cells are treated with monoclonal antibody Men-41 which recognizes the human CD4 antigen. As a cell passes through the flow chamber, it is intersected by a laser beam. Forward light scatter is proportional to the cell size and side scatter is related to cell granularity which allows separation of WBCs based on size and granularity. Analysis of CD4 - PE fluorescence signal helps in delineating subpopulation. Data was analyzed by cell quest software.

Statistical tests included mean, standard deviation, ANOVA (analysis of variance), chi-square test $\left(\mathrm{c}^{2}\right)$. The data was entered in Microsoft Office 2010 Excel worksheet and statistical analysis was done using Statistical Package for Social Sciences Software (SPSS) version 21. Descriptive statistics were applied: $\mathrm{p}$ - value less than 0.05 was considered statistically significant.

\section{Results:}

During the study period, 204 HIV - infected patients were referred to the haematology department, AFIP and included in this study. The age ranged from three years to 65 years. Mean age was $35.3 \pm 9.5$ years. The majority of $91(40.6 \%)$ cases were in the age group of $31-40$ years followed by 55 (27.0\%) cases in 21 to 30 years age group. There were 132 (64.7\%) males and 72 (35.3\%) females in this study with male to female ration 1.8: 1. Table - I shows the demographic data of the patients.
Table-I

Demographic data of the patients as per age and sex $(n=204)$

\begin{tabular}{cl} 
Age (in years) & Sex \\
\hline Range: $3-65$ & Male: $132(64.7 \%)$ \\
Mean: 35.3 & Female: $72(35.3 \%)$ \\
& M : F= 1.8 : 1 \\
\hline
\end{tabular}

$\mathrm{M}=$ Male; $\mathrm{F}=$ Female

In this study haematological parameters that have been included were haemoglobin (Hb) level, RBC count, haematocrit (Hct), absolute values (MCV, MCH, MCHC), RDW, ESR, TLC, absolute neutrophil, lymphocyte, monocyte and eosinophil count, platelet count and CD4 count. Out of 204 patients, 17 (8.3\%) cases had haemoglobin level equal to or less than 10.0 $\mathrm{g} / \mathrm{dl}, 60$ (29.4\%) cases had haemoglobin level in between $10.1 \mathrm{~g} / \mathrm{dl}$ and $12.0 \mathrm{~g} / \mathrm{dl}$ and 127 (62.3\%) cases had more than $12.0 \mathrm{~g} / \mathrm{dl}$. In case of haematocrit, 19 (9.3\%) cases had Hct equal to or less than $0.30 \mathrm{~L} / \mathrm{L}, 85$ (41.7\%) cases had in between $0.31 \mathrm{~L} / \mathrm{L}$ and $0.36 \mathrm{~L} / \mathrm{L}$ and $100(49.0 \%)$ cases had more than $>0.36 \mathrm{~L} / \mathrm{L}$. Out of 204 cases, 154 (75.5\%) cases had Erythrocyte Sedimentation rate (ESR) less than $20 \mathrm{~mm}$ in the $1^{\text {st }}$ hour and 50 (24.5\%) cases had more than $20 \mathrm{~mm}$ in the $1^{\text {st }}$ hour. RBC count ranged from $2.9 \times 10^{12} / \mathrm{L}$ to $5.2 \times 10^{12} / \mathrm{L}$ in case of female and in case of male it was from $3.2 \times 10^{12} / \mathrm{L}$ to 4.7 X $10^{12} / \mathrm{L}$. In 24 (11.8\%) cases RBC count was equal to or less than $3.0 \times 10^{12} / \mathrm{L}, 79(38.7 \%)$ cases had in between $3.1 \times 10^{12} / \mathrm{L}$ and $4.0 \times 10^{12} / \mathrm{L}$ and 101 (49.5\%) cases had more than $4.0 \times 10^{12} / \mathrm{L}$.

Mean Corpuscular Volume (MCV) ranged from $62.6 \mathrm{fl}$ to $124.5 \mathrm{fl}$. Nineteen cases (9.3\%) had MCV equal to or less than $76 \mathrm{fl}, 104$ (51.0\%) cases had in between 76 $\mathrm{fl}$ and $96 \mathrm{fl}$ and 81 (39.7\%) cases had more than $96 \mathrm{fl}$. Mean Corpuscular Haemoglobin (MCH) ranged from 18.2 picograms to 43.7 picograms. Seventy eight (38.2\%) cases had MCH within normal range (29 \pm 2.5 pg), 45 (22.1) cases had MCH equal to or less than 27.0 pg and 83 (40.7\%) cases had more than 32 pg. Mean Corpuscular Haemoglobin Concentration (MCHC) ranged from $29.1 \mathrm{~g} / \mathrm{dl}$ to $36.9 \mathrm{~g} / \mathrm{dl}$. Out of 204 cases, 20 (9.8\%) cases had MCHC equal to or less than $31.5 \mathrm{~g} /$ dl, 97 (47.5\%) cases had MCHC in between $31.5 \mathrm{~g} / \mathrm{dl}$ and $34.5 \mathrm{~g} / \mathrm{dl}$ and 87 (42.6\%) cases had more than 34.5 g/dl. Red Cell Distribution Width - Co-efficient of Variation (RDW - CV) ranged from $10.3 \%$ to $35.2 \%$. In 10 (4.9\%) cases, RDW - CV was equal to or less 
than $11.6 \%, 124$ (60.8\%) cases had in between $11.6 \%$ and $14 \%$, 70 (34.3\%) cases had more than $14 \%$.

Total Leucocyte Count (TLC) in this study ranged from $2.1 \times 10^{9} / \mathrm{L}$ to $15.4 \times 10^{9} / \mathrm{L}$. Ten $(4.9 \%)$ cases had leucopenia (<4.0 X 10\%/L), 19 (9.3\%) had leucocytosis and 175 (85.8\%) cases had leucocyte count within normal range. Absolute neutrophil count ranged from $9.0 \times 10^{9}$ / L to $13.9 \times 10^{9} / \mathrm{L}$. Neutropenia $\left(<2.0 \times 10^{9} / \mathrm{L}\right)$ was found in 20 (9.8\%), 18 (8.8) cases had neutrophilia (> $7.0 \mathrm{X}$ $\left.10^{9} / \mathrm{L}\right)$ and $166(81.4 \%)$ cases had absolute neutrophil count in between $2.0 \times 10^{9} / \mathrm{L}$ and $7.0 \times 10^{9} / \mathrm{L}$. Absolute lymphocyte count ranged from $0.6 \times 10^{9} / \mathrm{L}$ to $6.5 \times 10^{9} /$ L. The majority of 133 (65.2\%) cases had absolute lymphocyte count within the normal range (from $1.0 \mathrm{X}$ $10^{9} / \mathrm{L}$ to $\left.3.0 \times 10^{9} / \mathrm{L}\right), 12$ (5.9\%) cases had lymphopenia $\left(<1.0 \times 10^{9} / \mathrm{L}\right)$ and 59 (28.9\%) cases had lymphocytosis ( $\left.>3.0 \times 10^{9} / \mathrm{L}\right)$. Absolute monocyte count ranged from $0.1 \times 10^{9} / \mathrm{L}$ to $2.0 \times 10^{9} / \mathrm{L}$. Only one $(0.5 \%)$ case had monocytopenia $\left(<0.2 \times 10^{9} / \mathrm{L}\right)$, seven $(3.4 \%)$ cases had monocytosis ( $\left.>1.0 \times 10^{9} / \mathrm{L}\right)$ and rest of the 196 (96.1\%) cases had absolute monocyte count within the normal range $\left(0.2 \times 10^{9} / \mathrm{L}\right)$ to $\left.1.0 \times 10^{9} / \mathrm{L}\right)$. In this study, 68
(33.3\%) cases had eosinophilia (> $\left.0.5 \times 10^{9} / \mathrm{L}\right)$, absolute eosinophil count ranged from $0.03 \times 10^{9} / \mathrm{L}$ to $0.5 \times 10^{9}$ / L. Eosinophenia was not found in this study. Platelet count ranged from $60.0 \times 10^{9} / \mathrm{L}$ to $573 \mathrm{X} 10^{9} / \mathrm{L}$. Only seven (3.4\%) cases had thrombocytopenia (<150 X 10\% L), 189 (92.7\%) cases had platelet count in between 150 X $10^{9} / \mathrm{L}$ and $400 \mathrm{X} 10^{9} / \mathrm{L}$, eight (3.9\%) cases had thrombocytosis (> $400 \times 10^{9} / \mathrm{L}$ ). CD4 lymphocyte count was in between 52 cells/cmm and 908 cells/cmm in this study. Out of 204 cases 65 (31.9\%) had CD4 count less than 200 cells/cmm, 117 (57.3\%) cases had CD4 count in between 200 cells/cmm and 499 cells/cmm and 22 (10.8\%) cases had more than 500 cells/cmm. Table - II shows the pattern of haematological parameters in HIV - infected persons in this study.

Common haematological abnormalities found in this study were anaemia, raised ESR, leucopenia, leucocytosis, neutropenia, neutrophilia, lymphopenia, lymphocytosis, monocytopenia, monocytosis, eosinophilia, thrombocytopenia, thrombocytosis and low CD4 lymphocyte count. Table - III shows the frequency and percent of these findings.

\section{Table-II}

Pattern of haematological parameters in HIV- infected persons $(n=204)$

\begin{tabular}{|c|c|c|c|}
\hline $\mathrm{ESR}\left(\mathrm{mm}\right.$ in $1^{\mathrm{st}}$ & $6-17(\mathrm{M})$ & $19 \pm 28$ & $\mathrm{P}<0.001$ \\
\hline \multirow[t]{2}{*}{ hour) } & $5-50(\mathrm{~F})$ & $20 \pm 28$ & $\mathrm{P}<0.0001$ \\
\hline & $9.0-17.2(\mathrm{M})$ & $12.5 \pm 3.6$ & $\mathrm{P}>0.0001$ \\
\hline \multirow{2}{*}{$\mathrm{Hb}(\mathrm{g} / \mathrm{dl})$} & $7.8-15.2(\mathrm{~F})$ & $11.6 \pm 3.0$ & $\mathrm{P}>0.0001$ \\
\hline & $3.2-4.7(\mathrm{M})$ & $4.0 \pm 1.6$ & $\mathrm{P}>0.0001$ \\
\hline RBC count $(\mathrm{X} \mathrm{10} 12 / \mathrm{L})$ & $2.9-5.2(\mathrm{~F})$ & $3.8 \pm 1.6$ & $\mathrm{P}>0.001$ \\
\hline \multirow[t]{2}{*}{ Hct $(\mathrm{L} / \mathrm{L})$} & $0.27-0.47(\mathrm{M})$ & $0.37 \pm 0.10$ & $\mathrm{P}>0.0001$ \\
\hline & $0.27-0.45(\mathrm{~F})$ & $0.35 \pm 0.08$ & $\mathrm{P}>0.001$ \\
\hline $\operatorname{MCV}(\mathrm{fl})$ & $62.6-124.5$ & $93.1 \pm 28.4$ & $\mathrm{P}<0.001$ \\
\hline MCH (pg) & $18.2-43.7$ & $37.8 \pm 11.2$ & $\mathrm{P}<0.0001$ \\
\hline MCHC (g/dl) & $29.1-36.9$ & $34.1 \pm 4.0$ & $\mathrm{P}<0.001$ \\
\hline RDW - CV (\%) & $10.3-35.2$ & $14.1 \pm 5.4$ & $\mathrm{P}<0.001$ \\
\hline $\operatorname{TLC}\left(\mathrm{X} 10^{9} / \mathrm{L}\right)$ & $2.1-15.4$ & $7.6 \pm 5.0$ & $\mathrm{P}<0.0003$ \\
\hline $\operatorname{ANC}\left(\mathrm{X} 10^{9} / \mathrm{L}\right)$ & $0.9-13.9$ & $4.1 \pm 4.0$ & $\mathrm{P}<0.0001$ \\
\hline ALC (X10/L) & $0.6-6.5$ & $2.4 \pm 2.0$ & $\mathrm{P}<0.0001$ \\
\hline $\mathrm{AMC}\left(\mathrm{X} 10^{9} / \mathrm{L}\right)$ & $0.1-2.0$ & $0.6 \pm 0.4$ & $\mathrm{P}<0.0001$ \\
\hline $\operatorname{AEC}\left(\mathrm{X} 10^{9} / \mathrm{L}\right)$ & $0.03-5.0$ & $0.5 \pm 0.8$ & $\mathrm{P}<0.0001$ \\
\hline PLC (X109/L) & $60-573$ & $265 \pm 152$ & $\mathrm{P}<0.0001$ \\
\hline CD4(/cmm) & $52-908$ & $278 \pm 214$ & $\mathrm{P}>0.0001$ \\
\hline Parameters & Range & Mean \pm 2SD & $P$ - value \\
\hline
\end{tabular}

M = Male; F = Female; RDW - CV = Red Cell Distribution Width; TLC = Total Leucocyte count; ANC = Absolute Neutrophil count; ALC = Absolute Lymphocyte count; AMC $=$ Absolute Monocyte count; $\mathrm{AEC}=$ Absolute Eosinophil count; PLT $=$ Platelet. $\mathrm{Z}$ test was done to analyze the data. 


\section{Table-III}

Common haematological abnormalities in HIV-infected persons $(n=204)$

\begin{tabular}{lcc} 
Findings & Frequency & Percentage (\%) \\
\hline Anaemia & 103 & 50.5 \\
ESR (> 20 mm in $1^{\text {st }}$ hour) & 50 & 24.5 \\
Leucopenia & 10 & 4.9 \\
Leucocytosis & 19 & 9.3 \\
Neutropenia & 20 & 9.8 \\
Neutrophilia & 18 & 8.8 \\
Lymphopenia & 12 & 5.9 \\
Lymphocytosis & 59 & 28.9 \\
Monocytopenia & 01 & 0.5 \\
Monocytosis & 07 & 3.4 \\
Eosinophilia & 68 & 33.3 \\
Thrombocytopenia & 07 & 3.4 \\
ThrombocytosisCD4 count $(<$ & 0865 & 3.931 .9 \\
200/cmm) & & \\
CD4 count (200/cmm to 499/cmm) & 117 & 57.4 \\
CD4 count (>500/cmm & 22 & 10.8 \\
\hline
\end{tabular}

Table-IV

Comparison of number of anaemia cases in present study with others

\begin{tabular}{lccc} 
Authors & No of anaemia cases & Total cases & Percentage (\%) \\
\hline Parinitha et al & 210 & 250 & 84.0 \\
Karcher et al Tripathi et al & 17561 & 19774 & 89.082 .4 \\
Sitalakshmi et al & 27 & 42 & 64.2 \\
Kalousti et al & 34 & 40 & 85.0 \\
Present study & 103 & 204 & 50.5 \\
\hline
\end{tabular}

Table-V

\section{Comparison of morphological patterns of blood picture in present study with other studies}

\begin{tabular}{lccccccccc} 
Patterns of blood picture & \multicolumn{2}{c}{ Parinitha et al } & \multicolumn{3}{c}{ Khandekar et al } & \multicolumn{2}{c}{ Tripathi et al } & \multicolumn{2}{c}{ Present study } \\
& No & $\%$ & No & $\%$ & No & $\%$ & No & $\%$ \\
\hline Normocyticnormochromic blood picture & 101 & 48.1 & & 13 & 17.6 & 101 & 49.5 & \\
Normocytic normochromic anaemia & 29 & 13.7 & 68 & 48.7 & 54 & 79.9 & 28 & 13.7 \\
Microcytic hypochromic anaemia & 18 & 8.6 & 15 & 10.7 & 04 & 5.4 & 10 & 4.9 \\
Macrocytic anaemia & 15 & 7.2 & 32 & 29.9 & 03 & 4.1 & 30 & 14. \\
Anaemia of Chronic Disorder & - & - & - & - & - & - & 35 & 17.2 \\
Dimorphic anaemia & 47 & 22.4 & 25 & 17.9 & & - & - & - \\
\hline Total & 210 & 100 & 140 & 100 & 74 & 100 & 204 & 100 \\
\hline
\end{tabular}




\section{Table-VI}

Comparison of haematological parameters in patients with different CD4 counts

\begin{tabular}{lccccc} 
Parameters & $\begin{array}{c}\text { CD4 }>500 \\
\text { cells/cmm } \\
(\mathrm{n}=22)\end{array}$ & $\begin{array}{c}\text { CD4 200-400 } \\
\text { cells/cmm } \\
(\mathrm{n}=117)\end{array}$ & $\begin{array}{c}\text { CD4 }<200 \\
\text { cells/cmm } \\
(\mathrm{n}=65)\end{array}$ & $\begin{array}{c}\text { Statistical } \\
\text { test }\end{array}$ & $\mathrm{p}$ - value \\
\hline Anaemia (No of cases) & $09(41.0 \%)$ & $39(33.3 \%)$ & $55(84.6 \%)$ & $\mathrm{c}^{2}=45.28$ & $\mathrm{P}<0.0001$ \\
Total leucocyte count (mean $\pm \mathrm{SD})$ & $8.1 \pm 2.8$ & $7.8 \pm 2.4$ & $7.0 \pm 2.5$ & $\mathrm{~F}=5.0$ & $\mathrm{P}<0.01$ \\
Leucopenia (No of cases) & $01(4.5 \%)$ & $02(1.7 \%)$ & $07(10.8 \%)$ & $4 \mathrm{c}^{2}=8.68$ & $\mathrm{P}<0.01$ \\
Absolute lymphocyte count (mean \pm SD) $)$ & $3.0 \pm 1.3$ & $2.7 \pm 0.9$ & $1.8 \pm 0.9$ & $\mathrm{~F}=0.04$ & $\mathrm{P}>0.05$ \\
Lymphopenia (No of cases) & $00(00 \%)$ & $00(00 \%)$ & $12(18.5 \%)$ & $\mathrm{c}^{2}=94.8$ & $\mathrm{P}<0.001$ \\
Platelet count (mean $\pm \mathrm{SD})$ & $265 \pm 78$ & $267 \pm 68$ & $254 \pm 95$ & $\mathrm{~F}=2.54$ & $\mathrm{P}>0.05$ \\
Thrombocytopenia (No of cases) & $01(4.5 \%)$ & $01(0.9 \%)$ & $05(7.7 \%)$ & $\mathrm{c}^{2}=5.99$ & $\mathrm{P}=0.05$ \\
ESR (mean \pm SD) & $22 \pm 13$ & $17 \pm 12$ & $22 \pm 16$ & $\mathrm{~F}=1.79$ & $\mathrm{P}>0.05$ \\
\hline
\end{tabular}

$\mathrm{c}^{2}=$ chi square test, $\mathrm{F}=$ analysis of variance $($ ANOVA) test.

\section{Discussion:}

Haematological abnormalities frequently encountered in HIV-infected individuals are anaemia, granulocyte disorders, thrombocytopenia, lymphomas, coagulopathies and vascular malignancies like Kaposi sarcoma. Although in the majority of cases, haematologic abnormalities are detected in middle or advanced stages of HIV infection, some of these like anaemia and thrombocytopenia have been reported to occur in early stages of HIV infection ${ }^{6}$.

The origin of haematological disorders in HIV infection remain incompletely understood, but has been attributed to dysfunctional haematopoiesis in bone marrow caused by several factors. These include severe nutritional stress in advanced stages of HIV infection, suppression of marrow by invading opportunistic infections or neoplasm, chronic disease associated changes and toxic effects of antiretroviral compounds (or other medications used to combat the complications of HIV disease). The possibility of HIV directly infecting the haematopoietic precursor cells and inhibiting their differentiation and development to mature cells, has been an attractive hypothesis for the origin of HIV associated dysfunctional haematopoiesis, but to date it remains, to a great extent, an incompletely understood phenomenon ${ }^{7}$.

In the present study, haemoglobin level ranged from $7.8 \mathrm{~g} / \mathrm{dl}$ to $17.2 \mathrm{~g} / \mathrm{dl}$ with the mean being $12.5 \mathrm{~g} / \mathrm{dl}$. The majority (50.5\%) of cases in this study had anaemia with haemoglobin level less than the lower limit of their respective age and sex. Parinitha SS et al reported haemoglobin ranged from $3.3 \mathrm{~g} / \mathrm{dl}$ to $19.3 \mathrm{~g} / \mathrm{dl}$ with the mean being $10.2^{8}$. Kaloutsi et al reported haemoglobin in the range of $3.8 \mathrm{~g} / \mathrm{dl}$ to $17.3 \mathrm{~g} / \mathrm{dl}$ and a mean of $10.8^{9}$. However Tracy et al $1^{10}$ reported mean closer to the present study of $11.4 \mathrm{~g} / \mathrm{dl}$.Mean haematocrit in this study was $0.37 \mathrm{~L} / \mathrm{L}$. Tripahtiet al ${ }^{11}$ reported a mean haematocrit of $0.28 \mathrm{~L} / \mathrm{L}$. A better haemoglobin and haematocrit level in this study may be due to inclusion of cases with early HIV infection and good treatment response. Mean RDW - CV was $14.1 \%$ in the present study. A closer observation was made by Schneider et $\mathrm{al}^{12}$. Mean RBC count was $4.1 \times 10^{12} / \mathrm{L}$ in this study with standard deviation of 0.81 . A similar observation was made by Parinitha SS et al ${ }^{8}$. Tripathi et al reported a mean RBC count of $3.1 \times 10^{12} / \mathrm{L}$ and a standard deviation of 0.36 among 55 AIDS patients ${ }^{11}$. In this study, mean MCV, MCH and MCHC were $93.1 \mathrm{fl}, 37.8$ pg and $34.1 \mathrm{~g} / \mathrm{dl}$ with standard deviation of $14.2 \mathrm{fl}, 5.6$ pg and $2.0 \mathrm{~g} / \mathrm{dl}$ respectively. Parinitha SS et al reported findings close to this study ${ }^{8}$. Tripathi et al reported a mean MCV, MCH and MCHC of $81.8 \mathrm{fl}, 27.6 \mathrm{pg}$ and $32.5 \mathrm{~g} / \mathrm{dl}^{11}$. Erythrocyte Sedimentation Rate (ESR) ranged from $5 \mathrm{~mm}$ in $1^{\text {st }}$ hour to $70 \mathrm{~mm}$ in $1^{\text {st }}$ hour with mean and standard deviation were 19.5 and 14.1 respectively in this study. The majority of 154 (75.5\%) cases had ESR less than $20 \mathrm{~mm}$ in $1^{\text {st }}$ hour. Thirty 34 (16.7\%) cases had ESR equal to or more than $40 \mathrm{~mm}$ in 
$1^{\text {st }}$ hour. Raised ESR found in HIV - infected persons may be related to chronic nature of HIV infection ${ }^{8}$.

In the present study, anaemia was observed in 103 (50.5\%) cases. Paranitha et $\mathrm{al}^{8}$ reported anaemia in $84.0 \%(210 / 250)$ Kaloutsi et al reported anaemia in 85\% $(34 / 40)^{9}$, Karcher et al reported anaemia in 89\% (175/ 197) of cases $^{13}$ and Tripathi et al in $82.4 \%$ (61/74) of cases ${ }^{11}$. However Sitalakshmiet al ${ }^{14}$ reported anaemia in $64.2 \%$ (27/42) of cases which closer compared to the present study. This difference in anaemia in different study may be due to variation in large sample size and treatment response. Table - IV shows a comparison of number of anaemia cases in the present study with other studies.

Macrocytosis without anaemia was found in 81 (39.7\%) cases. Treatment with reverse transcriptase inhibitors will cause macrocytosis because they interfere with DNA production, which may lead to megaloblastic changes. Most patients with HIV who are being treated with reverse transcriptase inhibitors will display macrocytosis without anaemia. This indicates medications compliance by the patient, and no treatment is necessary ${ }^{15}$.The most common type of anaemia was anaemia of chronic disorder (ACD) observed in 35/103 (34.0\%) cases, followed by macrocytic anaemia in 30/ 103 (29.1\%) cases. Table - V shows the comparison of morphological patterns of blood picture in the present studies with other studies.

Mean Total Leucocyte Count (TLC) was 4.1 X $10^{9} / \mathrm{L}$. Paranitha et al ${ }^{8}$ reported mean of TLC $5.8 \times 10^{9} / \mathrm{L}$, Kaloutsi et $\mathrm{al}^{9}$ reported a mean of $5.2 \times 10^{9} / \mathrm{L}$. The majority of 175 (85.8\%) cases had normal total leucocyte count. Patwardhanet $\mathrm{al}^{16}$ reported in $75.6 \%$ $(378 / 500)$ of cases almost similar observation.Leucopenia was seen in 10 (4.9\%) and leucocytosis 19 (9.3\%) cases. Neutropenia and neutrophilia were found in 20 (9.8\%) and 18 (8.8\%) cases respectively. In 12 (5.9\%) cases, lymphopenia and 59 (28.9\%) cases, lymphocytosis was observed in this study. Parinitha et $\mathrm{al}^{8}$ reported lymphopenia in 163 (65.2\%) cases out of 250 cases, Tracy et al ${ }^{12}$ in $70 \%$ $(14 / 20)$ and Tripathi et $\mathrm{al}^{11}$ in $25.6 \%$ (19/74) of cases.In the present study, monocytopenia was seen in one (0.5\%) cases and monocytosis was found in seven (3.4\%) cases. Eosinophilia was observed in 68 (33.3\%) cases in this study. Paranithaet $\mathrm{al}^{8}$ observed eosinophilia in 54 (21.6\%) cases and Khandekar et al ${ }^{17}$ in 16 (11.4\%) cases out of 140 cases.Thrombocytopenia was observed in seven (3.4\%) cases in this study. Paranitha et al ${ }^{8}$ reported thrombocytopenia in 45 (18\%) cases, Patwardhan et al ${ }^{16}$ in 65/500 (13\%) cases and Castello C et al ${ }^{5}$ in 121/925 (13\%) cases. However, Karcher et al ${ }^{13}$ reported thrombocytopenia in 88/196 (45\%) cases, much higher compared to the present study.

CD4 lymphocyte count is essential for assessment of immune status in HIV - infected persons as the pathogenesis of AIDS is largely attributed to a decrease in absolute CD4 cell count. CD4 cell counts are the criterion for categorizing HIV-related clinical conditions by CDC classification system for HIV infection ${ }^{18}$. Patients in the present study were divided into three groups based on absolute CD4 lymphocyte count.

Haematological parameters were compared in these three groups. The number of cases with anaemia, leucopenia, lymphopenia and thrombocytopenia increased with reducing CD4 cell counts. Mean total leucocyte count, mean absolute lymphocyte count was lower with reducing CD4 cell count. These parameters showed significant difference ( $\mathrm{p}$ value $<0.05$ ) between three groups with differing CD4 cell count. This indicates higher occurrence of anaemia, leucopenia, lymphopenia and thrombocytopenia with progression of disease.These haematological findings almost correlate with Paranitha et $\mathrm{al}^{8}$. Table - VI shows the comparison of haematological parameters in patients with different CD4 cell counts.

\section{Conclusion:}

Haematological manifestations are common in HIV infected patients. Anaemia is the most common manifestation and the most frequent form is anaemia of chronic disorder followed by macrocytic anaemia. A proportion of patients also show leucopenia and thrombocytopenia. Incidence of anaemia, leucopenia and thrombocytopenia correlates with disease progression. The present study also showed significant correlation of absolute lymphocyte count with CD4 cell count. Thus absolute lymphocyte count can be used as a predictor of CD4 count and also to assess the stage of the disease in centres where CD4 count evaluation is not available. 


\section{References:}

1. Fauci AS, Lane HC. Human immunodeficiency virus disease: AIDS and related disorders. In: Kasper DL, Faici AS, Longo DL, Braunwald E, Hauser SL, Jameson JL, editors. Harrison's principles of internal medicine volume 1, USA: Mc Grow Hill Companies, 2005; p. 1076 - 1098.

2. Gourevitch MN. The epidemiology of HIV and AIDS current trends. Med Clin North Am. 1996 Nov; 80 (6): 1223 - 1238.

3. Bangladesh Serological Surveillance Survey 2006.

4. UNAIDS report on the global AIDS report. UNAIDS $10^{\text {th }}$ Anniversary Special Edition, Geneva, 2006.

5. Costello C. Haematological abnormalities in human immunodeficiency virus (HIV) disease. J ClinPathol 1988; 41: $711-715$.

6. Khiangle L, Vidyabati RK, Singh MK, Bilasini DS, Rajen ST. Study of serum lipid profile in human immunodeficiency virus (HIV) infected patients. JIACM 2007; 8: 307 - 311.

7. Basu A, Ghosh K, Banerjee K. Bone marrow involvement in HIV infection: light, electron and immune electron microscopic studies. Indian J Hematol and Blood Transf. 1999; 17 (4): 76 - 86.

8. Parinitha SS, Kulharni MH. Haematological changes in HIV infection with correlation to CD4 cell count. Australas Med J, 2012; 5 (3): 157 - 162.

9. Kaloutsi V, Kohlmeyer U, Maschek H, NafeR, Choritz H, Amor A. Comparison of bone marrow and hematologic findings in patients with human immunodeficiency virus infection and those with myelodysplastic syndromes and infectious diseases. Am J Clin Pathol, 1994; 101(2): $123-129$.
10. Treacy M, Lai L, Costello C, Clark A. Peripheral blood and bone marrow abnormalities in patients with HIV related disease. Br J Haematol, 1987; 65:289-94.

11. Tripathi AK, Kalra P, Misra R, Kumar A, Gupta N. Study of bone marrow abnormalities in patients with HIV disease. JAPI, 2005; 53:105-10. [PubMed]

12. Schneider DR, Picker LJ. Myelodysplasia in acquired immunodeficiency syndrome. Am J Clin Pathol, 1985; 84(2):144-52.

13. Karcher DS, Frost AR. Bone marrow in human immunodeficiency virus (HIV)-related disease morphology and clinical correlation. Am J Clin Pathol. 1991 Jan; 95(1):63-71.

14. Sitalakshmi S, Srikrishna A, Damodar P. Hematologic changes in HIV infection. Indian J Pathol Microbiol. 2003; 46(2): 180-3.

15. Green D, Sudre P, Anwar D, Goehring C, saaidia A, Hirschel B. causes of macrocytosis in HIV - infected patients not treated with zidovudine. Swiss HIV Cohort Study. J Infect, 2000; 40 (2): 160 - 163.

16. Patwardhan MS, Gowlikar AS, Abhyankar JR, Atre MC. Hematologic profile of HIV positive patients. Ind J Pathol Microbiol, 2002; 45(2):147-50.

17. Khandekar MM, Deshmukh SD, Holla VV, Rane SR, Kakrani AL. Profile of bone marrow examination in HIV/AIDS patients to detect opportunistic infections, especially tuberculosis. Indian J Pathol Microbiol, 2005; 48(1): 7 -12.

18. NACO annual report 2009-10 (last updated on June 1, 2010) Available from: http://www.nacoonline.org/Quick_Links/ Director y_of_HIV_Data/. [Last accessed on 2010 June 4]. 